\title{
ДЕРЖАВНЕ УПРАВЛІННЯ ОХОРОНОЮ ЗДОРОВ'Я ТА ПРОБЛЕМА СингуляРнОстІ
}

М. В. Банчук

\section{Національна академія державного управління при Президентові України}

\begin{abstract}
Розглянуті питання динаміки забезпеченості населення України лікарями в світлі реалізації управлінської парадигми щодо адекватної та своєчасної інтерпретації інформації з регіонів. Проведено паралелі $з$ ознаками інформаційної сингулярності.
\end{abstract}

Ключові слова: державне управління охороною здоров'я, інформаційна сингулярність, технологічна сингулярність, кадровий потенціал.

\section{ГОСУДАРСТВЕННОЕ УПРАВЛЕНИЕ ЗДРАВОХРАНЕНИЕМ И ПРОБЛЕМА СИНГУЛЯРНОСТИ}

Национальная академия государственного управления при Президенте Украины

Рассмотрены вопросы обеспечения населения Украины врачами в свете реализации управленческой парадигмы относительно адекватной и своевременной интерпретации информационной сингулярности.

Ключевые слова: государственное управление здравохранением, информационная сингулярность, технологическая сингулярность, кадровый потенциал.

\section{THE HEALTH CARE STATE ADMINISTRATION AND THE SINGULARITY PROBLEMS}

\section{The National Academy of Public Administration attached to the President of Ukraine}

The questions of doctors supply dynamics of the Ukraine population in the light of the administrative paradigm realization that is capable adequately and in - time interpret information from regions are considered. Parallels are conducted with the signs of informative singularity.

Key words: government administration of health care, informative singularity, technological singularity, skilled potential.

Вступ. Виклики сучасного розвитку країни визначають державне управління як динамічну систему, здатну адаптувати інститути державної влади i, передусім, виконавчої, до потреб суспільства, що нестримно змінюються в процесі структурних реформ. Пошук нової управлінської парадигми, здатної адекватно та своєчасно інтерпретувати нові реалії, органічно пов'язаний із практичною реалізацією завдання підтримки соціальної системи в стані динамічної рівноваги. Актуальність пошуку подібної парадигми обумовлена ризиками виникнення технологічної й інформаційної сингулярності. При цьому під терміном «технологічна сингулярність» розуміють нескінченне зростання технологій за кінцевий період часу. Отже, він визначає момент у часі, коли технічний прогрес стане настільки швидким і складним, що виявиться недоступним розумінню.

Під інформаційною сингулярністю зазвичай розуміють відрізок часу, коли інформаційний обсяг, що множиться в геометричній прогресії, набуває лавиноподібного зростання. В цьому випадку вкрай складним стає оцінювання валідності і релевантності інформації, що поступає.

У державному управлінні проблеми інформаційної сингулярності стають особливо актуальними при забезпеченні відповідності державної та регіональної політики. Ефективність державного управління регіоном характеризується мірою відповідності резуль-

(c) М. В. Банчук 
татів перетворення регіону цілям його розвитку. Критерієм ефективності реформування державного управління на регіональному рівні $є$ здатність регіональних структур влади успішно вирішувати регіональні проблеми на основі узгодження наслідків світових процесів із особливостями державних інтересів і специфікою локального (регіонального) ресурсного потенціалу в певному нормативно-правовому просторі.

Метою роботи $є$ аналіз змінення стратегії управління кадровим потенціалом у сучасних умовах при наявності ризиків інформаційної сингулярносгі.

Результати дослідження та їх обговорення. Провідне місце в кадровому потенціалі охорони здоров'я в Україні займають медичні кадри, що працюють у закладах охорони здоров'я системи МОЗ України. Структура медичних кадрів у розрізі спеціальностей, їх кваліфікація впливає на динаміку якісних показників галузі в цілому.
Тенденції розвитку кадрового потенціалу в Україні характеризуються низкою тенденцій. Постійно скорочується кількість медичних працівників на тлі загального зменшення чисельності населення, що забезпечує відносну стабільність динаміки показників на 10 тис. населення (рис. 1).

Це ж саме можна побачити за розрахунками динаміки чисельності лікарів у сільській місцевості (рис. 2).

Проте, якщо показник забезпечення населення лікарями має досить хаотичну динаміку з тенденцією до підвищення, то забезпечення населення середнім медичним персоналом (СМП) стабільно знижується (рис. 3).

Зауважимо, що темпи зниження забезпеченості населення СМП у 4 рази вищі за темпи зростання забезпечення населення лікарями (забезпеченість СМП знижується на 0,84 од., а забезпеченість ліка-

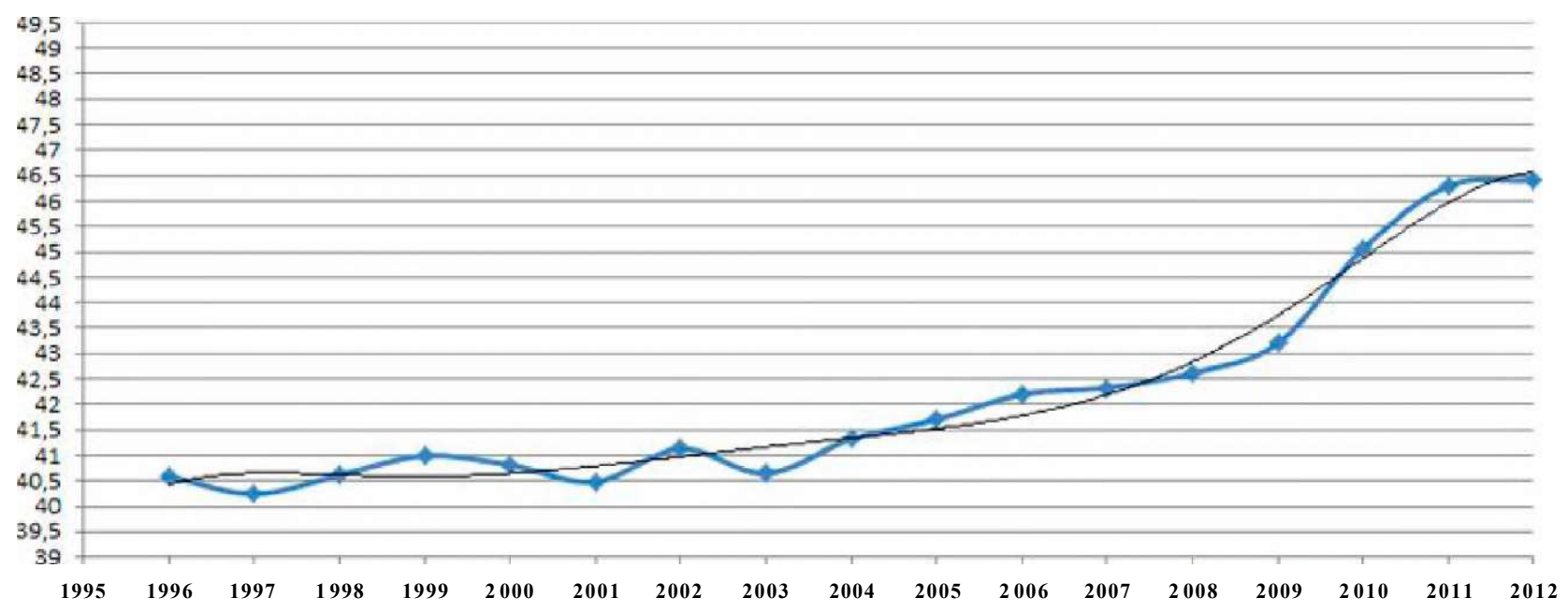

Puc. 1. Динаміка забезпеченості населення України лікарями (без стоматологів) на 10 тис. населення.

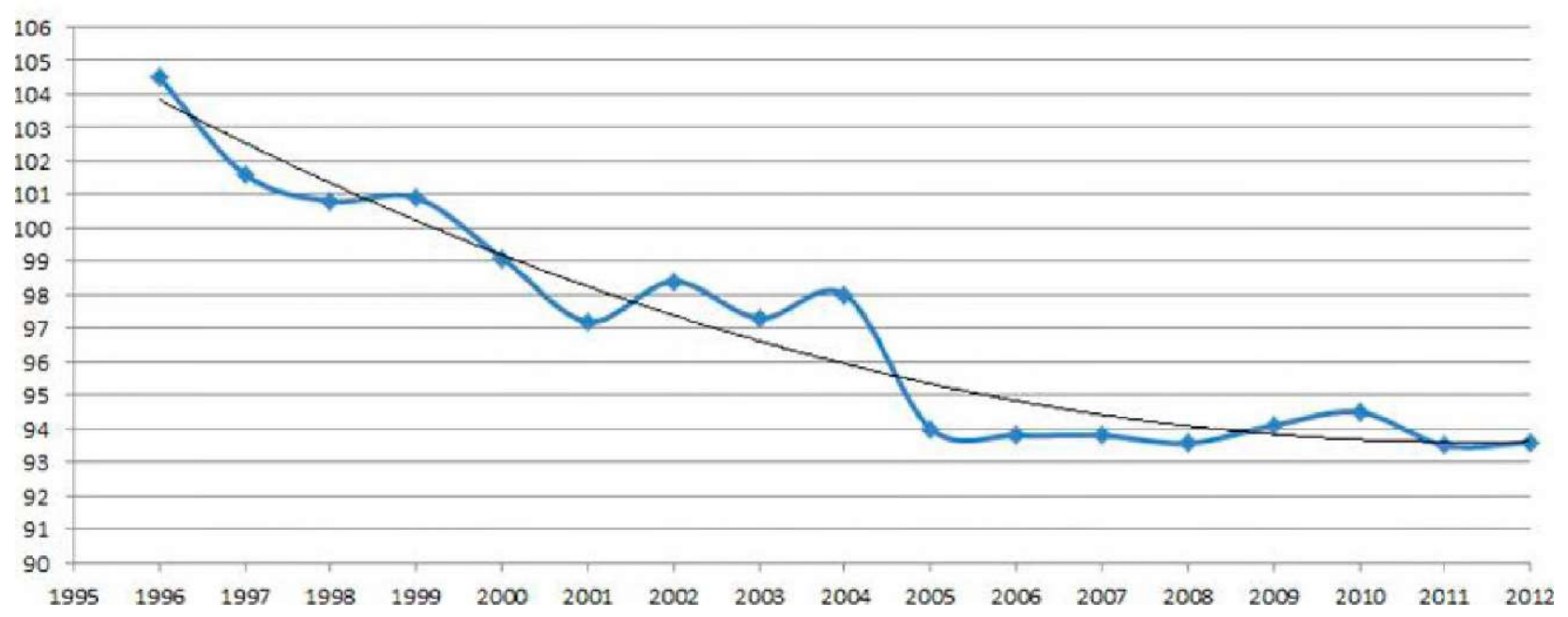

Puc. 2. Динаміка чисельності лікарів у сільських лікувально-профілактичних закладах МОЗ України. 


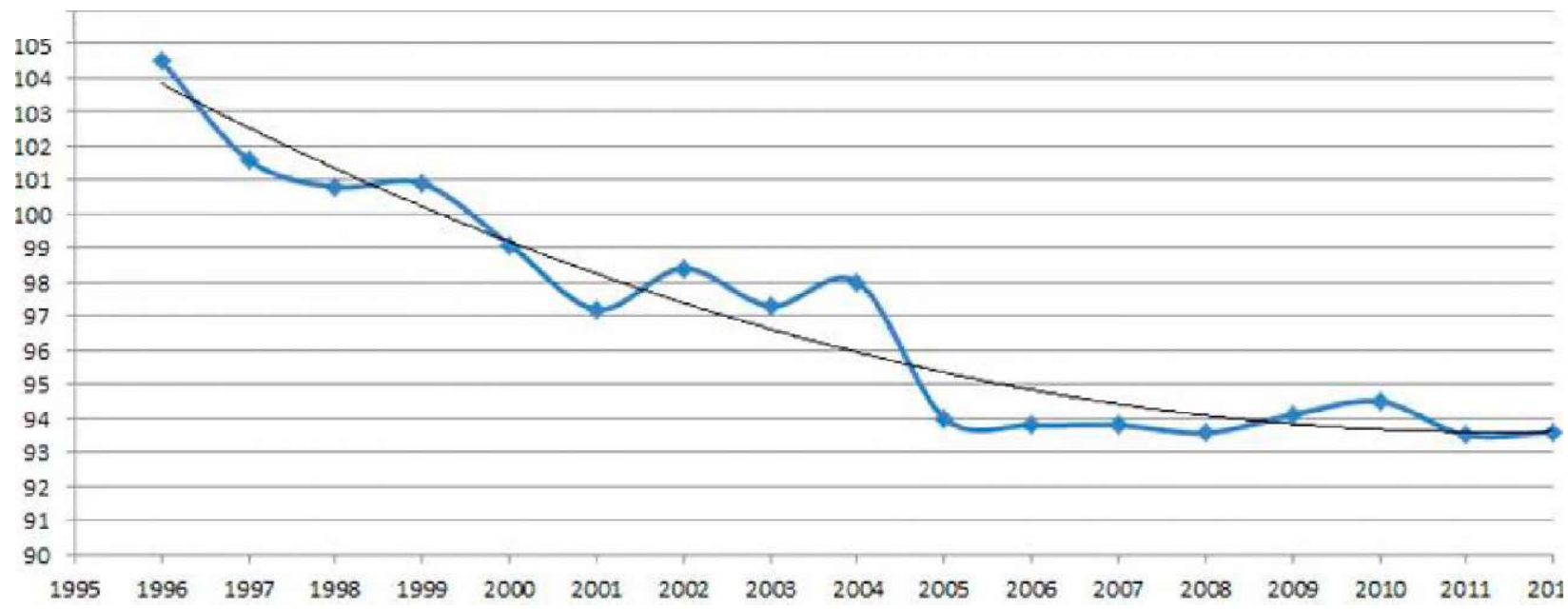

Puc. 3. Динаміка забезпечення населення України середніми медичними працівниками.

рями підвищується на 0,18 од. щорічно). Про це свідчать показники надійності апроксимації динамічних рядів: коефіцієнти детермінації щодо лікарів (як за їх чисельністю, так і за забезпеченістю на 10 тис. населення) є нижчими за показники щодо СМП.

Довготривала тенденція скорочення медичного персоналу характеризується такими даними: від'ємний приріст кількості лікарів за період 1994 2000 pр. щорічно складав 1142 чол., а у 2000-2008 pp. - 559 чол. Чисельність СМП у зазначені періоди в щорічному обчисленні становила відповідно 7767 і 7994 чол. Різноспрямовані абсолютні розміри скорочення чисельності лікарів у щорічних вимірах погіршують умови апроксимації та обумовлюють більш стабільні показники співвідношення чисельності лікарів і СМП, ніж порівняльні динамічні характерис- тики їх забезпеченості на 10 тис. населення. У відносних показниках забезпеченості на 10 тис. населення тренд по лікарях характеризується підвищенням щорічно на 0,16 од., водночас тренд по СМП щорічно знижується на 0,87 од.

Довготривала динаміка показника забезпеченості населення України лікарями характеризується тенденцією до підвищення. Цей показник, як похідний від чисельності лікарів і населення, відображає тенденції змін складових: випереджальні темпи зменшення кількості населення порівняно з темпами зниження чисельності лікарів зумовлюють зростання показника забезпеченості та його стабілізацію останніми роками.

Перелічені тенденції, на жаль, абсолютно не гармонізовані в часі та не корельовані між собою в регіонах (рис. 4).

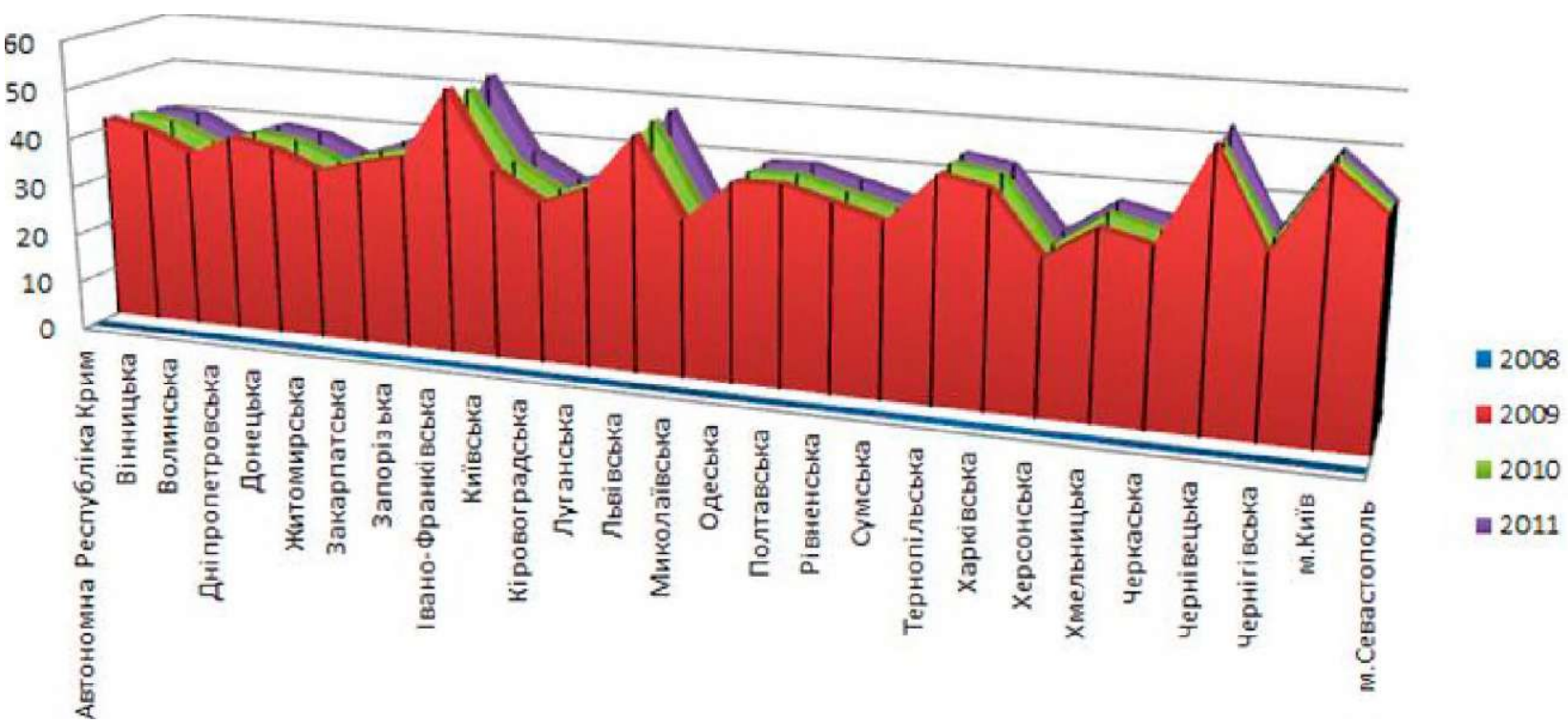

Puc. 4. Рівні забезпеченості лікарями у регіонах на 10 тис. населення за 2008-2011 роки. 
Як можна бачити з рисунка 4, різниця між областями України складає до 30 \%. Ця різниця мало скорочується протягом декількох років. Однак причини та ризики неадекватного змінення кадрової ситуації не очевидні. Потрібні дані щодо мотивації лікарів, умови життя в регіонах, зміни цих умов у часі, особливості захворюваності населення тощо.

Окрім того, має бути проведено оцінювання валідності цієї інформації, надійні комунікації для доставки даних, відповідні алгоритми для оперативного та довгострокового відстеження ситуації.

Зазначене свідчить, що сьогодні наявні ознаки інформаційної сингулярності в проблемі державного управління галуззю.

Виклики, що стоять перед сучасною Україною, детермінують державне управління як динамічну

\section{Мітература.}

1. Аблязов Н. Технологическая сингулярность. Исследование предпосылок возникновения и последствий для человечества / Н. Аблязов. - Режим доступу: http:// philosophy.mipt.ru/f_lvsglb/f_lvsgxk/a_lxes5v.html.

2. Васюгова С. А. Информационное общество: исследование перспектив и проблем интеграции человека с компьютером. Технологическая сингулярность как новый этап обучения в образовании / С. А. Васюгова О. О. Варламов. систему, здатну адаптувати інститути державної влади i, передусім, виконавчої, до потреб суспільства, що нестримно змінюються в процесі структурних реформ. Тому виявлення шляхів і способів підвищення ефективності управління кадровою структурою галузі охорони здоров'я надзвичайно важливі. Проте вже сьогодні інформації для прийняття рішень буває недостатньо.

Висновки. 1. Проблеми інформаційної сингулярності стають особливо актуальними при забезпеченні відповідності державної та регіональної політики.

2. Причини та ризики неадекватного змінення кадрової ситуації в галузі охорони здоров'я не очевидні. Необхідні детальні та валідні дані щодо мотивації лікарів, умов життя в регіонах, змін цих умов у часі, особливостей захворюваності населення тощо.

- Режим доступу: http://Mo-alt.ru/2011-09-05-07-56-07.

3. Лехан В. М. Стратегія розвитку системи охорони здоров'я : український вимір /Лехан В. М. СлабкийГ. О., Шевченко М. В. // Новости медицины и фармации. - 2010. №4 (309).-С. 29-30.

4. Основні шляхи подальшого розвитку системи охорони здоров'я в Україні / [за заг. ред. В. М. Лехан, В. М. Рудого]. - К.: Вид-во Раєвського, 2005. -168 с. 